\title{
Elevated CSF levels of TACE activity and soluble TNF receptors in subjects with mild cognitive impairment and patients with Alzheimer's disease
}

\author{
Hong Jiang ${ }^{5,6}$, Harald Hampel ${ }^{2}$, David Prvulovic ${ }^{2}$, Anders Wallin ${ }^{3}$, Kaj Blennow ${ }^{3}$, Rena Li ${ }^{4}$ and Yong Shen ${ }^{1,5^{*}}$
}

\begin{abstract}
We recently reported that expression levels of tumor necrosis factor (TNF) receptors, TNFR1 and TNFR2, are significantly changed in the brains and cerebrospinal fluid (CSF) with Alzheimer's disease (AD). Moreover, we also found that, in an Alzheimer's mouse model, genetic deletion of TNF receptor (TNFR1) reduces amyloid plaques and amyloid beta peptides (A $\beta$ ) production through $\beta$-secretase (BACE1) regulation. TNF- $\alpha$ converting enzyme (TACE/ ADAM-17) does not only cleave pro- TNF- $\alpha$ but also TNF receptors, however, whether the TACE activity was changed in the CSF was not clear. In this study, we examined TACE in the CSF in 32 AD patients and 27 agematched healthy controls (HCs). Interestingly, we found that TACE activity was significantly elevated in the CSF from AD patients compared with HCs. Furthermore, we also assayed the CSF levels of TACE cleaved soluble forms of TNFR1 and TNFR2 in the same patients. We found that AD patients had higher levels of both TACE cleaved soluble TNFR1 (sTNFR1) and TNFR2 (STNFR2) in the CSF compared to age- and gender-matched healthy controls. Levels of sTNFR1 correlated strongly with the levels of sTNFR2 ( $r s=0.567-0.663, p<0.01$ ). The levels of both sTNFR1 and sTNFR2 significantly correlated with the TACE activity ( $r s=0.491-0.557, p<0.05)$. To examine if changes in TACE activity and in levels of cleaved soluble TNFRs are an early event in the course of AD, we measured these molecules in the CSF from 47 subjects with mild cognitive impairment (MCl), which is considered as a preclinical stage of AD. Unexpectedly, we found significantly higher levels of TACE activity and soluble TNFRs in the $\mathrm{MCl}$ group than that in AD patients. These results suggest that TACE activity and soluble TNF receptors may be potential diagnostic candidate biomarkers in $\mathrm{AD}$ and $\mathrm{MCl}$.
\end{abstract}

Keywords: Alzheimer's disease, soluble tumor necrosis factor receptor, tumor necrosis factor converting enzyme, ADAM-17, biomarker

\section{Introduction}

Extensive evidence supports the concept that neuroinflammation plays a significant role in the neuropathogenesis of Alzheimer's disease (AD) [1-7]. Tumor necrosis factor- $\alpha$ (TNF- $\alpha$ ) is one of the major inflammatory cytokines and plays a key role in $\mathrm{AD}[8]$ by regulating two TNF receptors, TNFR1 and TNFR2, through various signal transduction pathways, which finally converge to a common mechanism of neuronal death. We recently reported [9] that the expression levels of the two TNF receptors are significantly changed in AD

\footnotetext{
* Correspondence: yshen@rfdn.org

${ }^{1}$ Center for Advanced Therapeutic Strategies for Brain Disorders, Roskamp Institute, Sarasota, FL 34243, USA

Full list of author information is available at the end of the article
}

brain tissues; specifically TNFR1 is increased whereas TNFR2 is significantly decreased in AD brains. Our studies on double transgenic mice demonstrate that deletion of TNFR1 in Alzheimer transgenic APP23 mice results in reduction of brain amyloid plaques and $A \beta$ levels [10]. Furthermore, clinical evidence supports the concept that inhibiting the expression of TNF- $\alpha$ may result in cognitive improvement in $\mathrm{AD}$ patients $[11,12]$.

TNF- $\alpha$ functions through binding to its two receptor subtypes, TNFR1 and TNFR2 [8]. Interestingly, studies have shown that both TNFR1 and TNFR2 can be shed from the cell surface with TACE/ADAM17 to become soluble forms [13]. TACE is a transmembrane disintegrin metalloprotease that cleaves precursor TNF- $\alpha$ to generate soluble, secreted TNF- $\alpha$ in macrophages and

\section{C) Bïomed Central}


monocytes $[14,15]$. Both the cell-associated and the released forms of TNF are biologically active, but full inflammatory responses require the soluble form in at least some situations [16]. When TNFRs are shed by TACE, TNFR-mediated TNF-a signaling might be interrupted. Untill now, there are no reports regarding soluble TNFRs act as dominant-negative competitors to their receptor counterparts. Recently, soluble TNF receptors have been detected in CSF from preclinical AD patients [17]. However, it was not known whether TACE/ADAM-17 activity in the CSF would be changed. If TACE/ADAM17 is being shed from the brain cell membranes and leaks into the CSF after cleavage of the two TNF receptors, we would be able to detect TACE activity in the CSF throughout different stages of AD. Based on the evidence and rationales described above, we examined levels of TACE, and soluble TNF receptors in the CSF from AD patients and MCI subjects.

\section{Materials and methods Subjects}

CSF samples were obtained from total 103 patients in two independent clinical research center: the Alzheimer Memorial Center, Department of Psychiatry, LudwigMaximilian University in Germany and the Department of Clinical Neuroscience, University of Goteborg, Sahlgren's University Hospital, Sweden. A total of 103 individuals were recruited from the above centers, 32 probable AD patients, $44 \mathrm{MCI}$ subjects and 27 agematched healthy individuals. As we described previously $[18,19]$, diagnosis of $\mathrm{AD}$ was made according to the National Institute of Neurological and Communicative Disorders and Stroke (NINCDS-ADRDA) criteria [20], including the Mini-Mental State Examination (MMSE) and MCI was diagnosed according to the Petersen criteria [21]. MCI subjects performed 1.5 SD below the age-adjusted reference average in memory scales, as assessed using the Consortium to Establish a Registry for Alzheimer's Disease (CERAD) cognitive battery [22]. This battery included verbal learning, recognition, and recall tests; global cognitive function and activities of daily living were unimpaired. Controls were cognitively healthy individuals who underwent spinal anesthesia for surgery of the urinary tract or lower extremities. Psychiatric comorbidity was excluded by means of history, clinical examination, and Composite International Diagnostic Interview [23]. All the controls were cognitively normal according to Consortium to Establish a Registry for Alzheimer's Disease cognitive battery performance (within $1 \mathrm{SD}$ in all subtests), and the participants had no complaints of cognitive impairment and had no history of dementia, did not show any signs of other psychiatric illnesses, and were followed up clinically for 3 years to exclude development of any neurodegenerative disease. To avoid spinal anesthesia as a potential confounding factor when collecting CSF, CSF was obtained immediately after inserting the needle and just before application of the anesthetic drug. CSF samples were obtained at baseline by lumbar puncture in the L3/L4 or L4/L5 interspace. The CSF samples were gently mixed to avoid possible gradient effects, centrifuged, and stored at $-80^{\circ} \mathrm{C}$ pending biochemical analyses, without being thawn and re-frozen. All the procedures were approved by the institutional review boards (IRB) of the respective institutions, and consent forms were signed by the patients before sample collection.

\section{Assays of soluble TNFR (sTNFR) in the CSF}

Both sTNFR1 and sTNFR2 were measured using a commercially available immunoassay according to the instructions provided by the manufacturer "R\&D System" (Minneapolis, MN, USA). We added $50 \mu \mathrm{L}$ of assay diluent to each well, then added $200 \mu \mathrm{L}$ sample to each well, incubating for $2 \mathrm{hrs}$ at room temperature. After aspirating and washing 3 times, $200 \mu \mathrm{L}$ conjugate were added to each well and incubated for $2 \mathrm{hrs}$ at room temperature. After aspirating and washing 3 times, we added $200 \mu \mathrm{L}$ substrate solution to each well, incubated $20 \mathrm{~min}$ at RT, protecting from light. At last, we added $50 \mu \mathrm{L}$ stop solution to each well, and read at $450 \mathrm{~nm}$ within $30 \mathrm{~min}$. The detection limit of the assay is $7.8 \mathrm{pg} / \mathrm{ml}$ of human recombinant sTNFR with an inter-assay variation of $<10 \%$.

\section{Assays of levels of TACE activity}

TACE activity was measured using a solution-based assay. $7.5 \mu \mathrm{L}$ of CSF was first diluted to $90 \mu \mathrm{L}$ with running buffer (1 M Tris $\mathrm{HCl}, 10 \mathrm{mM} \mathrm{ZnCl} 2)$. Ten microliter TACE substrate (R\&D System, Minneapolis, MN, USA) was added to a final concentration. The enzymatic activity was measured using a microplate reader set to $320 \mathrm{~nm}$ of the excitation and $405 \mathrm{~nm}$ of the emission. The specific enzymatic activity of TACE is calculated $\mathrm{FU} / \mathrm{min}$.

\section{Statistical analysis}

The Statistical Package for Social Sciences (SPSS 11.5 for Windows) was used for statistical comparisons. Results were presented as mean \pm S.E.M. Paired-Samples $\mathrm{T}$ test was used to compare differences between means in two groups. Spearman's correlation coefficient was used for correlation analysis. A probability value of $\mathrm{p}<0.05$ was taken to indicate statistical significance.

\section{Results}

Levels of TACE activity and sTNFRs in CSF in the different diagnostic groups

As shown in Table 1, there was no statistically significant difference in age between the $\mathrm{AD}(71.4 \pm 7.4)$ and 
Table 1 Baseline data in the patients with $\mathrm{MCl}, \mathrm{AD}$ and the controls (Assay targets were in CSF)

\begin{tabular}{llll}
\hline Measured variables & $\begin{array}{l}\text { Controls } \\
(\mathbf{n}=\mathbf{2 7})\end{array}$ & $\begin{array}{l}\mathbf{M C l} \\
(\mathbf{n}=\mathbf{4 4})\end{array}$ & $\begin{array}{l}\text { AD } \\
(\mathbf{n}=\mathbf{3 2})\end{array}$ \\
\hline Age (years) & $55.6 \pm 10.0$ & $71.9 \pm 7.1^{\mathrm{b}}$ & $71.4 \pm 7.4^{\mathrm{b}}$ \\
\hline Sex (M/F) & $17 / 10$ & $23 / 21$ & $11 / 21$ \\
\hline MMSE at baseline (0-30 p) & $28.7 \pm 1.1$ & $26.2 \pm 2.2^{\mathrm{b}}$ & $20.1 \pm 4.8^{\mathrm{a}}$ \\
\hline CSF sTNFR1 $(\mathrm{pg} / \mathrm{mL})$ & $705.0 \pm 66.2$ & $972.1 \pm 50.7^{\mathrm{b}}$ & $930.9 \pm 52.5^{\mathrm{b}}$ \\
\hline CSF sTNFR2 $(\mathrm{pg} / \mathrm{mL})$ & $409.6 \pm 130.2$ & $602.6 \pm 38.7^{\mathrm{b}}$ & $832.1 \pm 54.1^{\mathrm{a}}$ \\
\hline CSF TACE activity (FU/min) & $53.1 \pm 6.6$ & $91.2 \pm 6.6^{\mathrm{c}}$ & $82.0 \pm 6.8^{\mathrm{b}}$ \\
\hline
\end{tabular}

Values are means \pm S.D., except as noted otherwise. Abbreviations: AD patients with stable cognitive functions; MCl: mild cognitive impairment; Controls, healthy controls, with unimpaired cognition after at least 3 years follow-up; MMSE, mini-mental state examination; sTNFR, soluble tumor necrosis factor- $\alpha$ receptor; CSF, cerebrospinal fluid.

a $p<0.001$ vs. Controls.

${ }^{\mathrm{b}} p<0.05$ vs. Controls.

${ }^{c} p<0.01$ vs. Controls.

the MCI group $(71.9 \pm 7.1)(\mathrm{p}>0.05)$. There was significant difference of age between the $\mathrm{AD} / \mathrm{MCI}$ and the $\mathrm{HC}$ group $(55.6 \pm 10)(\mathrm{p}<0.05)$. There was no difference in gender distribution among the three groups $(\mathrm{p}>0.01)$. MMSE scores differed significantly between AD patients $(20.1 \pm 4.8)$ and $\mathrm{HC}$ subjects $(28.7 \pm 1.1) \mathrm{p}<0.001)$, MCI patients $(26.2 \pm 2.2)$ and HC subjects $(\mathrm{p}<0.05)$, and $\mathrm{AD}$ and MCI patients $(\mathrm{p}<0.001)$.

Interestingly as shown in Figure 1, in MCI, TACE activity levels $(91.2 \pm 6.6 \mathrm{FU} / \mathrm{min})$ and sTNFR1 (972.1 $\pm 50.7 \mathrm{pg} / \mathrm{mL}$ ) did not fall in between AD (TACE: 82.0 $\pm 6.8 \mathrm{FU} / \mathrm{min}$; sTNFR1: $930.9 \pm 52.5 \mathrm{pg} / \mathrm{mL}$ ) and $\mathrm{HC}$ subjects (TACE: $53.1 \pm 6.6 \mathrm{FU} / \mathrm{min}$; sTNFR1: $705 \pm$
$66.2 \mathrm{pg} / \mathrm{mL}$ ) (Table 1). There was a significant difference in TACE activity levels between AD and $\mathrm{HC}$ (df $=1 ; \mathrm{p}<0.001)$, between MCI and $\mathrm{HC}(\mathrm{df}=1 ; \mathrm{p}<$ 0.01 ), and between $\mathrm{AD}$ and MCI patients ( $\mathrm{df}=1$; $\mathrm{p}<$ 0.05). The sTNFR1 levels in the CSF from both AD and MCI patients were significantly higher than those in $\mathrm{HC}$ subjects (Paired-Samples $\mathrm{T}$ test, $\mathrm{p}<0.05$ ). There was a significant difference in sTNFR1 levels between $\mathrm{AD}$ and $\mathrm{MCI}(\mathrm{df}=1 ; \mathrm{p}<0.01)$, between $\mathrm{AD}$ and $\mathrm{HC}(\mathrm{df}=1 ; \mathrm{p}<0.05)$, and between MCI and $\mathrm{HC}$ $(\mathrm{df}=1 ; \mathrm{p}<0.01)$. However, sTNFR2 levels in MCI patients $(602.6 \pm 38.7)$ fell into between AD patients $(832.1 \pm 54.1 \mathrm{pg} / \mathrm{mL})$ and $\mathrm{HC}$ subjects $(409.6 \pm 130.2$ $\mathrm{pg} / \mathrm{mL}$ ). Moreover, there was a significant difference in sTNFR2 of CSF between MCI patients and HC subjects $(\mathrm{p}<0.05)$, and between $\mathrm{AD}$ and $\mathrm{HC}$ subjects (Paired-Samples T test $\mathrm{p}<0.001$ ).

\section{Significant correlations between baseline levels of sTNFR1} and STNFR2 in CSF

In the subjects with MCI, AD patients and $\mathrm{HC}$ subjects, there were positive and strong correlations between sTNFR1 and sTNFR2 in CSF $\left(r_{s}=0.567\right.$ 0.690, $\mathrm{p}<0.01 ; \mathrm{r}_{\mathrm{s}}=0.567-0.663, \mathrm{p}<0.01$ ) (Table 2 Figures 2, 3).

\section{Correlations between the baseline levels of sTNFRs and TACE activity}

The levels of both sTNFRs in CSF correlated strongly with the CSF activity of TACE $\left(\mathrm{r}_{\mathrm{s}}=0.491-0.557, \mathrm{p}<\right.$ 0.05) (Table 2 Figures 1, 4, 5).

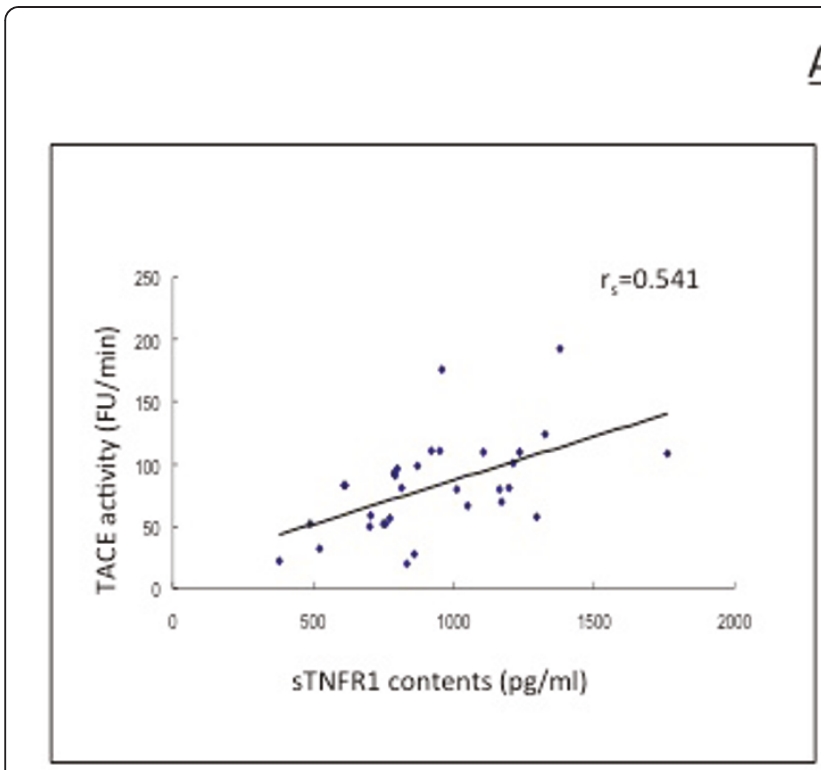

\section{$\underline{A D}$}

Figure 1 The baseline levels of soluble TNF receptors, type I and type 2 (sTNFR1 and sTNFR2) in CSF correlate positively to the TACE activity in $A D$ patients. 
Table 2 Correlations between baseline CSF levels of soluble TNF receptors and TACE activity

\begin{tabular}{llccc}
\hline CSF & & TACE & sTNFR1 & sTNFR2 \\
\hline Controls & sTNFR1 & $r_{\mathrm{s}}=0.491^{\mathrm{b}}$ & $/$ & $r_{\mathrm{s}}=0.567^{\mathrm{c}}$ \\
\cline { 2 - 5 } & sTNFR2 & $r_{\mathrm{s}}=0.557^{\mathrm{c}}$ & $r_{\mathrm{s}}=0.567^{\mathrm{c}}$ & $/$ \\
\hline $\mathrm{MCl}$ & sTNFR1 & $r_{\mathrm{s}}=0.400^{\mathrm{c}}$ & $/$ & $r_{\mathrm{s}}=0.690^{\mathrm{a}}$ \\
\cline { 2 - 5 } & sTNFR2 & $r_{\mathrm{s}}=0.311^{\mathrm{b}}$ & $r_{\mathrm{s}}=0.690^{\mathrm{a}}$ & $/$ \\
\hline $\mathrm{AD}$ & sTNFR1 & $r_{\mathrm{s}}=0.541^{\mathrm{c}}$ & $/$ & $r_{\mathrm{s}}=0.663^{\mathrm{a}}$ \\
& sTNFR2 & $r_{\mathrm{s}}=0.508^{\mathrm{c}}$ & $r_{\mathrm{s}}=0.663^{\mathrm{a}}$ & $/$
\end{tabular}

All data were collected at baseline. Abbreviations: CSF, cerebrospinal fluid; STNFR, soluble tumor necrosis factor- $\alpha$ receptor; AD: Alzheimer's disease; MCI: mild cognitive impairment; TACE: tumor necrosis factor-a converting enzyme.

${ }^{a} p<0.001$.

${ }^{\mathrm{b}} p<0.05$

${ }^{c} p<0.01$.

\section{Discussion}

In the present study, as shown in Table 1, we did see the age difference between healthy controls and $\mathrm{MCI}$ and healthy controls and AD patients. Although up to now, based on the published literatures, there is no direct evidence for a possible impact of age on TACE, it is possible that aging may contribute to TACE changes via different mechanisms. In this study, we investigated TACE and both sTNFR1 and sTNFR2 in the CSF from $\mathrm{AD}$ and MCI patients. Interestingly, the levels of sTNFR in CSF were significantly increased in the subjects with $\mathrm{AD}$ compared to age and sex-matched healthy controls. Moreover, the CSF levels of both types of sTNFR in the
AD subjects correlated strongly with TACE activity. These results suggest that the disease severity may affect the TACE activity.

Accumulating evidence supports the idea that neuroinflammation plays a significant role in the neuropathogenesis of AD [24]. Tumor necrosis factor- $\alpha$ (TNF- $\alpha$ ) is one of the major inflammatory cytokines produced by activated astrocytes and microglia. Increasing evidence now supports the concept that excess TNF- $\alpha$ plays a central role in AD $[8,25]$. TNF- $\alpha$ exerts its biological effects by binding to TNFR1 and TNFR2. Both receptors belong to a super family of transmembrane receptors that are defined by a similar cysteine-rich extracellular domain, however, the intracellular regions of TNFR1 and TNFR2 appear to be unrelated, suggesting distinct modes of activation of signal transduction pathways $[8,26,27]$. TNFR1 is constitutively expressed at low levels on all nucleated cells, TNFR2 has a higher affinity for TNF than TNFR1 and binds TNF better at lower concentrations $[9,28]$. It has been proposed that in advanced stages of AD once extensive amyloid plaques have formed, elevated levels of pro-inflammatory cytokines, including TNF- $\alpha$, may inhibit phagocytosis of toxic $A \beta$ species and/or hinder efficient plaque removal by brain resident microglia [29]. Proinflammatory cytokines attenuate microglial phagocytosis stimulated by $f A \beta$ or complement receptor 3 and argue that this may, in part, underlie the accumulation of $\mathrm{fA} \beta$-containing plaques within the AD brain. The proinflammatory suppression of $\mathrm{fA} \beta$-elicited phagocytosis is dependent on nuclear factor

\section{Health Control}
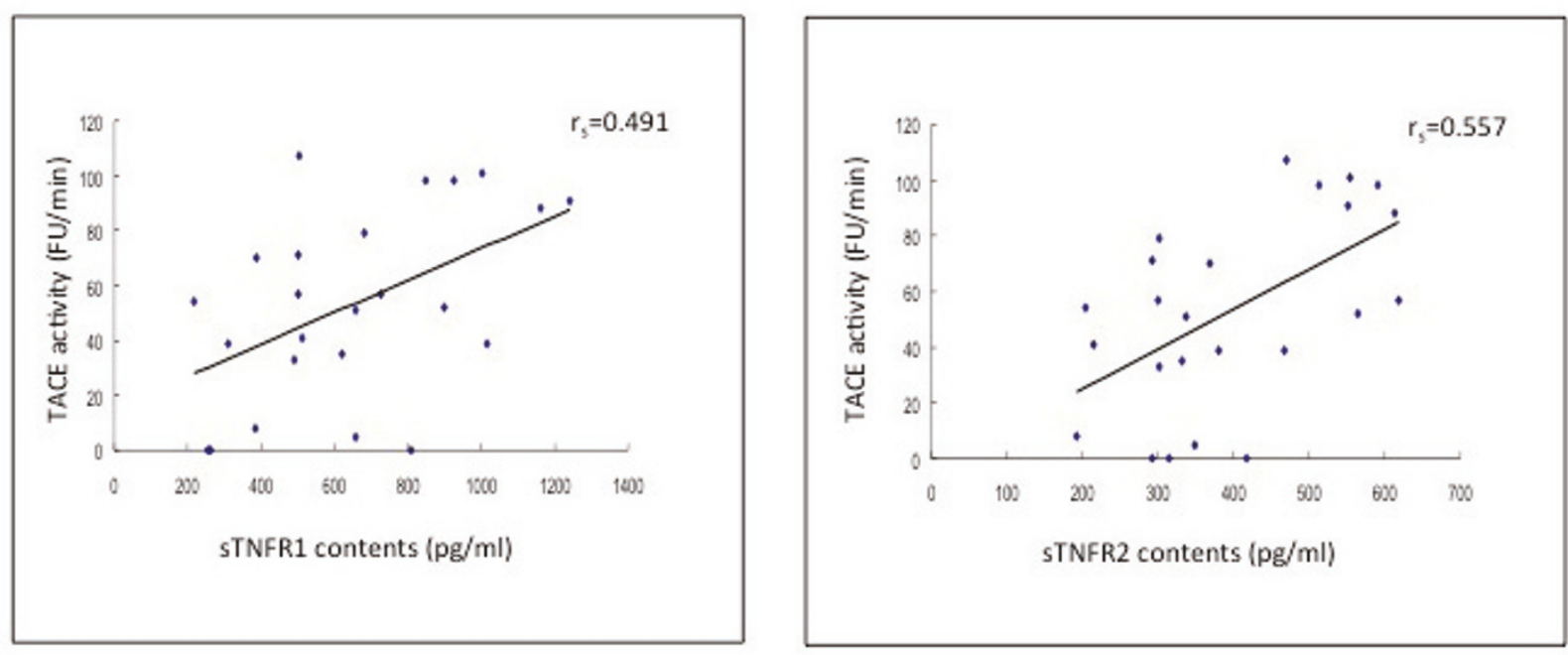

Figure 2 The baseline levels of soluble TNF receptors type 1 and type 2 (sTNFR1 and sTNFR2) in CSF correlate positively to the TACE activity in aged-matched healthy individuals. 


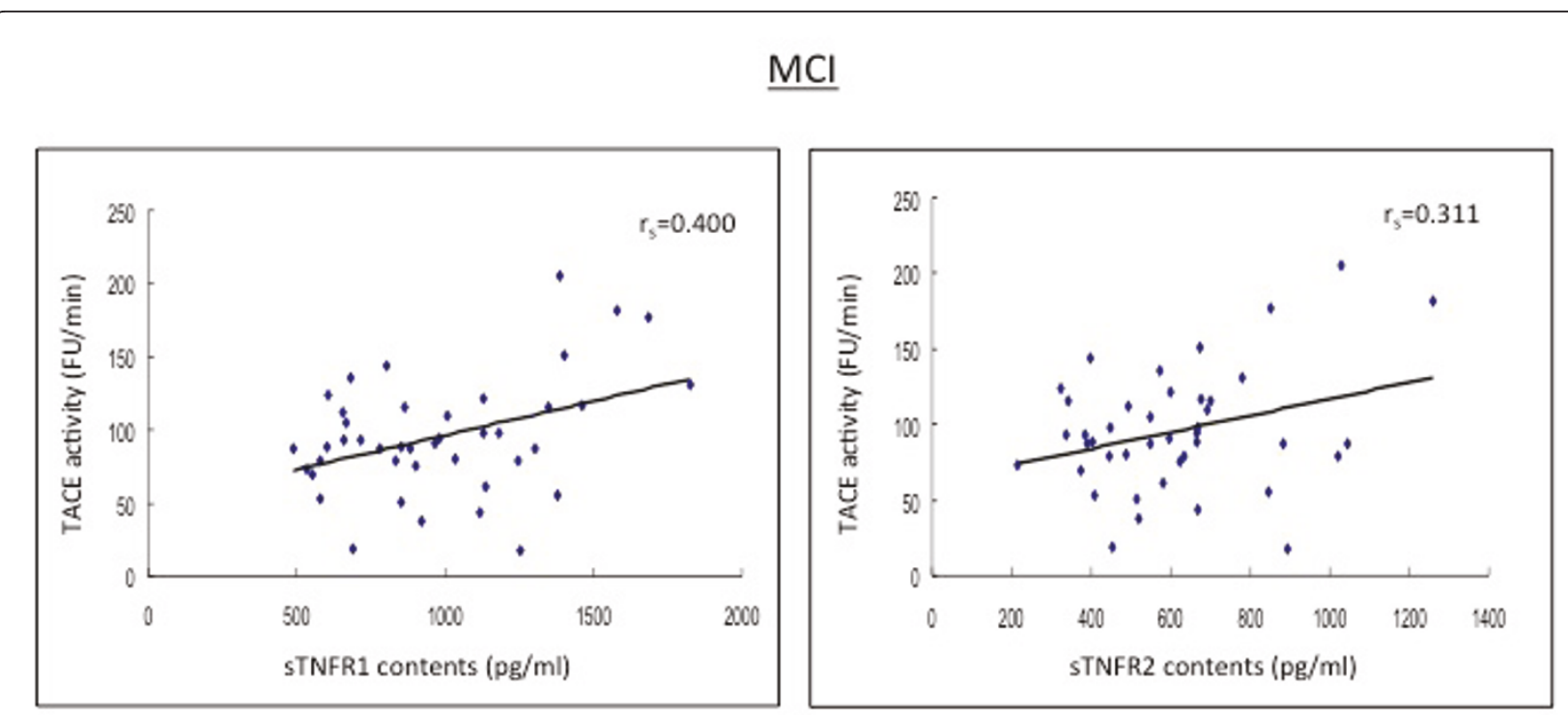

Figure 3 The baseline levels of soluble TNF receptors, type 1 and type 2 (sTNFR1 and sTNFR2) in CSF correlate positively to the TACE activity in $\mathrm{MCl}$ patients

kappaB activation [29]. In AD, excessive TNF- $\alpha$ activated TNFR1 through high affinity binding [9] and signaling accordingly suppresses $A \beta$ degradation by reducing the expression of insulin degrading enzyme [30] and affects $\mathrm{A} \beta$ production through upregulation of BACE expression [31] and $\gamma$-secretase activity [32]. In our study, the significantly higher levels of sTNFR1 in CSF of the patients with AD compared to age-matched controls indicated that in spite of its conversion into soluble forms, the TNFR1 signaling pathway was still existing in the presence of excessive TNF- $\alpha$, and may thus contribute to $A \beta$ production as discussed above. On the other hand, the activation of the TNFR2 signaling pathway may be neuroprotective [33]. The elevated levels of sTNFR2 in CSF as shown in the present study suggest that TNFR2 is deficient as we recently reported [9], possibly cleaved by TACE. This impaired TNFR2 signaling pathway might alleviate the neuroprotective effects and also promote $A \beta$ production.

We showed elevated levels of the TACE activity in CSF. Moreover, there were positive and significant
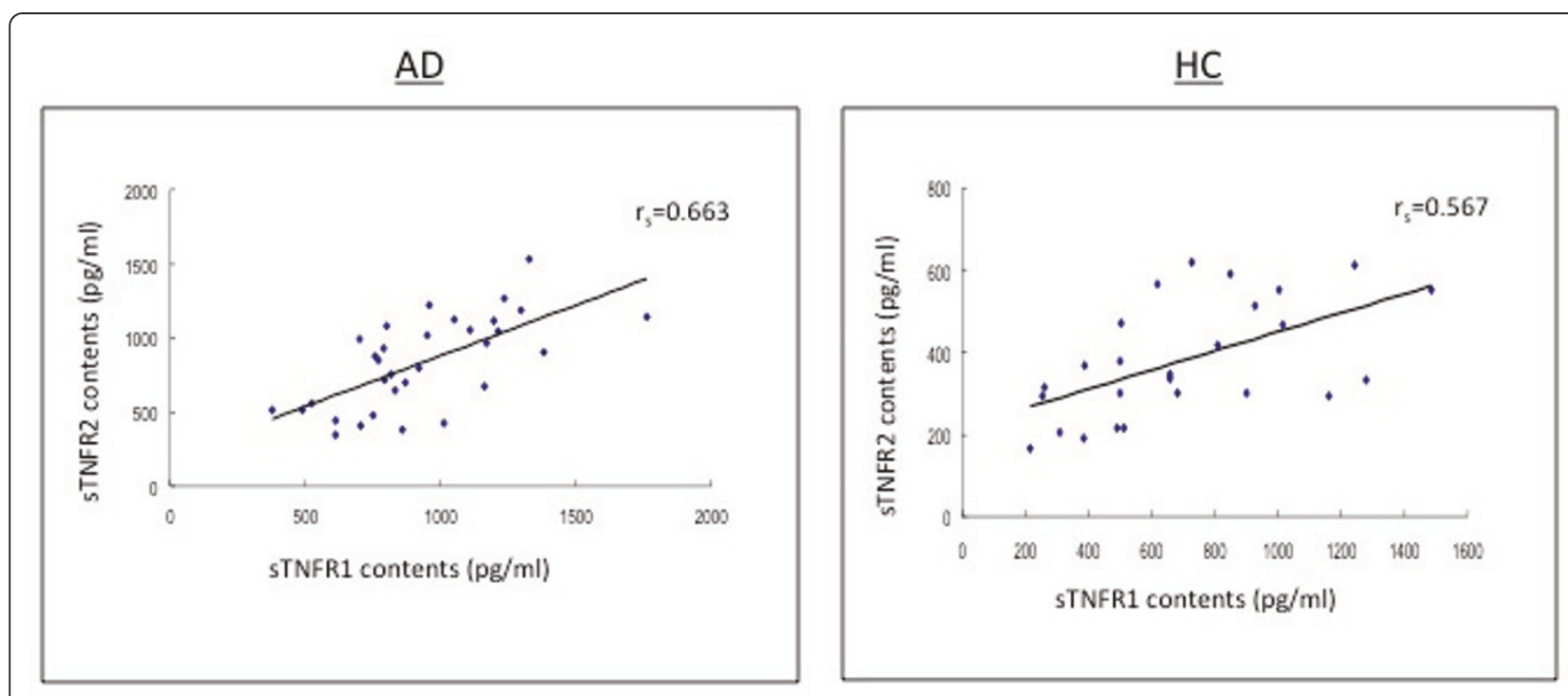

Figure 4 The levels of soluble TNF receptor type 1 (sTNFR1) in CSF correlate positively to the soluble TNF receptor type 2 (sTNFR2) in the CSF between AD patients and aged-matched healthy controls. 


\section{$\underline{\mathrm{MCl}}$}

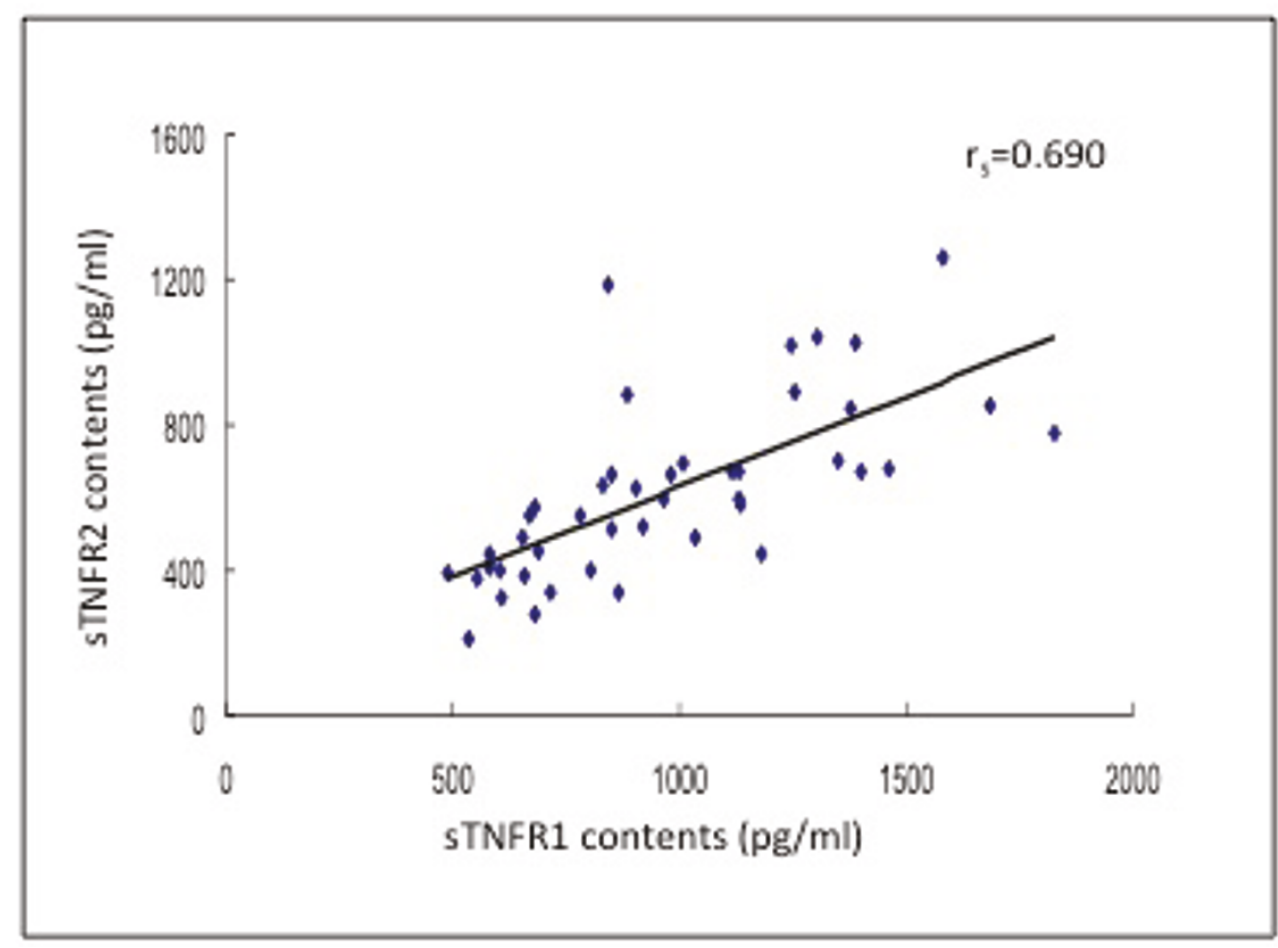

Figure 5 The levels of soluble TNF receptor type 1 (sTNFR1) in CSF correlate positively to the soluble TNF receptor type 2 (sTNFR2) in the CSF among the MCl patients.

correlations between both sTNFR levels and TACE activity in AD. TACE is a metalloprotease-disintegrin that releases several transmembrane proteins into soluble forms, including TNFR1 and TNFR2 [34,35]. Therefore, increased TACE activity would contribute to increased sTNFR as shown in the present study. These findings are in accordance with other reports that increased levels of TACE shed more sTNFRs [36,37].

Both but through different regulation mechanisms, $\beta$ - (BACE) and $\alpha$-(TACE) secretases contribute to $A \beta$ production. BACE-mediated cleavage of amyloid precursor protein (APP) at the $N$ terminus of the $A \beta$ sequence is the first step in the generation of $A \beta$ and BACE has been shown to be upregulated in sporadic AD brains $[38,39]$. TACE is also responsible for the $\alpha-$ secretase cleavage of APP $[40,41]$. Release of sAPP $\alpha$ precludes the formation of amyloidogenic peptides by BACE [42]. Although not presented in this study, there is general consensus that levels of CSF AB1-42 in AD are lower than those in ND [43]. The fact that TACE is increased in the CSF of AD might lead to the assumption that high TACE activity would parallel increased sAPP $\alpha$ and reduced A $\beta$ levels. However, the most abundant form of $A \beta$ - $A \beta 1-40$ - is not decreased in $\mathrm{AD}$, which speaks against a role of TACE activity in the modulation of CSF A $\beta$ levels. The observed reduction of $A \beta 1-42$ in CSF may be related to oligomerization and aggregation of $A \beta 1-42$ rather than to TACE activities. Indeed, several independent studies demonstrate that modifying TACE activity does not affect APP cleavage by BACE and A $\beta$ production [44-47]. This would explain why even increased TACE activity in $\mathrm{AD}$ it doesn't alter the $\mathrm{A} \beta$ production from APP. This was further supported by other reports that inhibition or knockdown of TACE does not affect sAPP formation and $\mathrm{A} \beta$ secretion under normal conditions $[40,48]$. TACE might not predominantly cleave APP in $\mathrm{AD}$ and plays a role only in the regulatory component of the $\alpha$-secretase processing of APP. Therefore, we suggest that TACE may predominantly cleave TNFRs rather than APP, and contribute to upregulation of $\mathrm{BACE}$ and consecutive increase of $\mathrm{A} \beta$ production through the TNFR signaling pathway as discussed above. 
In conclusion, this study shows elevated levels of sTNFRs and TACE activity in CSF, as well as correlations between them in patients with $\mathrm{AD}$ compared to age and sex-matched controls. These results further support the concept that the TNFR signaling pathway contributes to $A \beta$ production and to the subsequent cytotoxicity in the brain. sTNFRs and TACE may become valid diagnostics targets to determine AD.

\section{Acknowledgements}

This work was supported by grants from NIH/NIA025888 (YS) and Alzheimer Association (Zenith Award to YS), and supported by the Neuronal Coordination

Research Focus Frankfurt (NeFF), Neurodegeneration Branch, Alzheimer's Disease Project, awarded to $\mathrm{HH}$ and DP.

\section{Author details}

${ }^{1}$ Center for Advanced Therapeutic Strategies for Brain Disorders, Roskamp Institute, Sarasota, FL 34243, USA. ${ }^{2}$ Department of Psychiatry, Psychosomatic Medicine \& Psychotherapy, Goethe University, Frankfurt, Germany. ${ }^{3}$ Department of Clinical Neuroscience, University of Göteborg, Sahlgren's University Hospital, Mölndal, Sweden. ${ }^{4}$ Center for Hormone Advanced Science and Education Roskamp Institute, Sarasota, FL 34243, USA. ${ }^{5}$ Haldeman Laboratory of Molecular and Cellular Neurobiology, Sun Health Research Institute, Sun City, AZ 85351, USA. ${ }^{6}$ Current address: State Key disciplines: Physiology, Medical College of Qingdao University, Qingdao, China.

\section{Authors' contributions}

$\mathrm{HJ}$ performed bioassays and wrote the manuscript draft. $\mathrm{HH}, \mathrm{AW}$ and $\mathrm{KB}$ made clinical diagnosis for the subjects with $\mathrm{MCl}$ and patients with $\mathrm{AD}$ and also provided the CSF samples from these individuals. DP participated in manuscript drafting. $\mathrm{HH}$ and RL participated data analyses, experimental design discussing and manuscript drafting. YS initiated the project and designed the experiments and participated data analyses and overviewed manuscript drafting and finalized the paper. All authors have read and approved the final manuscript.

\section{Competing interests}

The authors declare that they have no competing interests.

Received: 2 July 2011 Accepted: 6 October 2011

Published: 6 October 2011

\section{References}

1. Eikelenboom P, Veerhuis R, van Exel E, Hoozemans JJ, Rozemuller AJ, van Gool WA: The early involvement of the innate immunity in the pathogenesis of late-onset Alzheimer's disease: neuropathological, epidemiological and genetic evidence. Curr Alzheimer Res 2011, 8:142-150.

2. Grammas P: Neurovascular dysfunction, inflammation and endothelial activation: implications for the pathogenesis of Alzheimer's disease. $J$ Neuroinflammation 2011, 8:26.

3. Kannappan R, Gupta SC, Kim JH, Reuter S, Aggarwal BB: Neuroprotection by Spice-Derived Nutraceuticals: You Are What You Eat! Mol. Neurobiol 2011.

4. Marchesi VT: Alzheimer's dementia begins as a disease of small blood vessels, damaged by oxidative-induced inflammation and dysregulated amyloid metabolism: implications for early detection and therapy. FASEB J 2010, 25:5-13.

5. McGeer EG, McGeer PL: Neuroinflammation in Alzheimer's disease and mild cognitive impairment: a field in its infancy. J Alzheimers Dis 2011, 19:355-361.

6. Krause DL, Müller N: Neuroinflammation, microglia and implications for anti-inflammatory treatment in Alzheimer's disease. Int I Alzheimers Dis 2010, 14:pii: 732806
7. Ray B, Lahiri DK: Neuroinflammation in Alzheimer's disease: different molecular targets and potential therapeutic agents including curcumin. Curr Opin Pharmacol 2009, 9:434-444.

8. Shen $Y$, He P, Zhong Z, McAllister $C$, Lindholm K: Distinct destructive signal pathways of neuronal death in Alzheimer's disease. Trends Mol Med 2006, 12:574-579.

9. Cheng X, Yang L, He P, Li R, Shen Y: Differential activation of tumor necrosis factor receptors distinguishes between brains from Alzheimer's disease and non-demented patients. J Alzheimers Dis 2010, 19:621-630

10. He P, Zhong Z, Lindholm K, Berning L, Lee W, Lemere C, Staufenbiel M, Li R, Shen Y: Deletion of tumor necrosis factor death receptor inhibits amyloid beta generation and prevents learning and memory deficits in Alzheimer's mice. J Cell Biol 2007, 178:829-841.

11. Tobinick EL, Gross H: Rapid cognitive improvement in Alzheimer's disease following perispinal etanercept administration. I Neuroinflammation 2008, $5: 2$

12. Sabbagh MN, Nural H, He P, Sirrel S, Belden C, Liebsack C, Li R, Shen Y: Rationale and strategy for thalidomide as a BACE 1 inhibitor for a phase II randomized clinical trial in mild to moderate Alzheimer's disease. International Conference of Alzheimer's Disease (ICAD), Hawaii; 2010

13. Ermert M, Pantazis $C$, Duncker HR, Grimminger F, Seeger W, Ermert L: In situ localization of TNFalpha/beta, TACE and TNF receptors TNF-R1 and TNF-R2 in control and LPS-treated lung tissue. Cytokine 2003, 22:89-100.

14. Moss ML, Milla ME, Burkhart W, Carter HL, Chen W-J, Clay WC, Didsbury JR, Hassler D, Hoffman CR, Kost TA, Lambert MH, Leesnitzer MA, McCauley P, McGeehan G, Mitchell J, Moyer M, Pahel G, Rocque W, Overton LK, Schoenen F, Seaton T, Su J-L, Warner J, Willard D, Becherer JD: Cloning of a disintegrin metalloproteinase that processes precursor tumour-necrosis factor-a. Nature 1997, 385:733-736.

15. Black R, Rauch CT, Kozlosky CJ, Peschon JJ, Slack JL, Wolfson MF, Castner BJ, Stocking KL, Reddy P, Srinivasan S, Nelson N, Boiani N, Schooley KA, Gerhart M, Davis R, Fitzner JN, Johnson RS, Paxton RJ, March CJ, Cerretti DP: A metalloproteinase disintegrin that releases tumour-necrosis factor-a from cells. Nature 1997, 385:729-733.

16. Ruuls SR, Hoek RM, Ngo VN, McNeil T, Lucian LA, Janatpour MJ, Korner $H$, Scheerens H, Hessel EM, Cyster JG, McEvoy LM, Sedgwick JD: Membranebound TNF supports secondary lymphoid organ structure but is subservient to secreted TNF in driving autoimmune inflammation. Immunity 2001, 15:533-543.

17. Buchhave $P$, Zetterberg $H$, Blennow $K$, Minthon L, Janciauskiene $S$, Hansson O: Soluble TNF receptors are associated with $A \beta$ metabolism and conversion to dementia in subjects with mild cognitive impairment. Neurobiol Aging 2010, 31:1877-1884

18. Ewers M, Zhong Z, Bürger K, Wallin A, Blennow K, Teipel SJ, Shen Y, Hampel H: Increased CSF-BACE 1 activity is associated with ApoE-epsilon 4 genotype in subjects with mild cognitive impairment and Alzheimer's disease. Brain 2009, 131:1252-1258

19. Zhong Z, Ewers M, Teipel S, Bürger K, Wallin A, Blennow K, He P, McAllister C, Hampel H, Shen Y: Levels of beta-secretase (BACE1) in cerebrospinal fluid as a predictor of risk in mild cognitive impairment. Arch Gen Psychiatry 2007, 64:718-726.

20. McKhann G, Drachman D, Folstein M, Katzman R, Price D, Stadlan EM: Clinical diagnosis of Alzheimer's disease: report of the NINCDS-ADRDA Work Group under the auspices of Department of Health and Human Services Task Force on Alzheimer's Disease. Neurology 1984, 34:939-944.

21. Petersen RC: Clinical practice. Mild cognitive impairment. N Engl I Med 2011, 364(23):2227-34

22. Morris JC, Heyman A, Mohs RC, Hughes JP, van Belle G, Fillenbaum G, Mellits ED, Clark C: The Consortium to Establish a Registry for Alzheimer's Disease (CERAD). Part I. Clinical and neuropsychological assessment of Alzheimer's disease. Neurology 1988, 39:1159-1165.

23. Robins LN, Wing J, Wittchen HU, Helzer JE, Babor TF, Burke J, Farmer A, Jablenski A, Pickens R, Regier DA, Sartorius N, Towle LH: The Composite International Diagnostic Interview. An epidemiologic Instrument suitable for use in conjunction with different diagnostic systems and in different cultures. Arch Gen Psychiatry 1988, 45:1069-1077.

24. Wyss-Coray T, Mucke L: Inflammation in neurodegenerative disease-a double-edged sword. Neuron 2002, 35:419-432.

25. Van Eldik L, Thompson WL, Ralay Ranaivo H, Behanna HA, Martin Watterson D: Glia proinflammatory cytokine upregulation as a 
therapeutic target for neurodegenerative diseases: function-based and target-based discovery approaches. Int Rev Neurobiol 2007, 82:277-296.

26. Dembic Z, Loetscher H, Gubler U, Pan YC, Lahm HW, Gentz R, Brockhaus M, Lesslauer W: Two human TNF receptors have similar extracellular, but distinct intracellular, domain sequences. Cytokine 1990, 2:231-237.

27. Tartaglia LA, Goeddel DV: Tumor necrosis factor receptor signaling. A dominant negative mutation suppresses the activation of the $55-\mathrm{kDa}$ tumor necrosis factor receptor. J Biol Chem 1992, 267:4304-4307.

28. Hajeer AH, Hutchinson IV: TNF-alpha gene polymorphism: clinical and biological implications. Microsc Res Tech 2000, 50:216-228.

29. Koenigsknecht-Talboo J, Landreth GE: Microglial phagocytosis induced by fibrillar beta-amyloid and IgGs are differentially regulated by proinflammatory cytokines. J Neurosci 2005, 25:8240-8249.

30. Yamamoto M, Kiyota T, Walsh SM, Liu J, Kipnis J, Ikezu T: Cytokinemediated inhibition of fibrillar amyloid-beta peptide degradation by human mononuclear phagocytes. J Immunol 2008, 181:3877-3886.

31. Yamamoto M, Kiyota T, Horiba M, Buescher JL, Walsh SM, Gendelman HE, Ikezu T: Interferon-gamma and tumor necrosis factor-alpha regulate amyloid-beta plaque deposition and beta-secretase expression in Swedish mutant APP transgenic mice. Am J Pathol 2007, 170:680-692.

32. Liao YF, Wang BJ, Cheng HT, Kuo LH, Wolfe MS: Tumor necrosis factoralpha, interleukin-1 beta, and interferon-gamma stimulate gammasecretase-mediated cleavage of amyloid precursor protein through a JNK-dependent MAPK pathway. J Biol Chem 2004, 279:49523-49532.

33. Shen Y, Li R, Shiosaki K: Inhibition of p75 tumor necrosis factor receptor by antisense oligonucleotides increases hypoxic injury and beta-amyloid toxicity in human neuronal cell line. J Biol Chem 1997, 272:3550-3553.

34. Peschon JJ, Slack JL, Reddy P, Stocking KL, Sunnarborg SW, Lee DC, Russell WE, Castner BJ, Johnson RS, Fitzner JN, et al: An essential role for ectodomain shedding in mammalian development. Science 1998, 282:1281-1284

35. Reddy P, Slack JL, Davis R, Cerretti DP, Kozlosky CJ, Blanton RA, Shows D, Peschon JJ, Black RA: Functional analysis of the domain structure of tumor necrosis factor-alpha converting enzyme. J Biol Chem 2000 275:14608-14614.

36. Canault M, Leroyer AS, Peiretti F, Leseche G, Tedqui A, Bonardo B, Alessi MC, Boulanger CM, Nalbone G: Microparticles of human atherosclerotic plaques enhance the shedding of the tumor necrosis factor-alpha converting enzyme/ADAM17 substrates, tumor necrosis factor and tumor necrosis factor receptor-1. Am J Pathol 2007, 171:1713-1723.

37. Wang J, Li Z, Al-Lamki R, Zuo N, Bradley JR, Wang L: The role of tumor necrosis factor-alpha converting enzyme in renal transplant rejection. Am J Nephrol 2010, 32:362-368.

38. Yang LB, Lindholm K, Yan R, Citron M, Xia W, Yang XL, Beach T, Sue L, Wong P, Price D, Li R, Shen Y: Elevated beta-secretase expression and enzymatic activity detected in sporadic Alzheimer disease. Nat Med 2003, 9:3-4.

39. Li R, Lindholm $K$, Yang $L B$, Yue $X$, Citron $M$, Yan $R$, Beach $T$, Sue $L$, Sabbagh M, Cai H, Wong P, Price D, Shen Y: Amyloid beta peptide load is correlated with increased beta-secretase activity in sporadic Alzheimer's disease patients. Proc Natl Acad Sci USA 2004, 101:3632-3637.

40. Buxbaum JD, Liu KN, Luo Y, Slack JL, Stocking KL, Peschon JJ, Johnson RS, Castner BJ, Cerretti DP, Black RA: Evidence that tumor necrosis factor alpha converting enzyme is involved in regulated alpha-secretase cleavage of the Alzheimer amyloid protein precursor. J Biol Chem 1998, 273:27765-27767.

41. Lammich S, Kojro E, Postina R, Gilbert S, Pfeiffer R, Jasionowski M, Haass C, Fahrenholz F: Constitutive and regulated alpha-secretase cleavage of Alzheimer's amyloid precursor protein by a disintegrin metalloprotease. Proc Natl Acad Sci USA 1999, 96:3922-3927.

42. De Strooper B, Annaert W: Proteolytic processing and cell biological functions of the amyloid precursor protein. J Cell Sci 2000, 113:1857-1870.

43. Blennow K, Hampel H, Weiner M, Zetterberg H: Cerebrospinal fluid and plasma biomarkers in Alzheimer disease. Nat Rev Neurol 2010, 6:131-144

44. Blacker M, Noe MC, Carty TJ, Goodyer CG, LeBlanc AC: Effect of tumor necrosis factor-alpha converting enzyme (TACE) and metalloprotease inhibitor on amyloid precursor protein metabolism in human neurons. $J$ Neurochem 2002, 83:1349-1357.
45. Dyrks T, Monning U, Beyreuther K, Turner J: Amyloid precursor protein secretion and beta A4 amyloid generation are not mutually exclusive. FEBS Lett 1994, 349:210-214.

46. Gandhi S, Refolo LM, Sambamurti K: Amyloid precursor protein compartmentalization restricts beta-amyloid production: therapeutic targets based on BACE compartmentalization. J Mol Neurosci 2004, 24:137-143.

47. LeBlanc AC, Koutroumanis M, Goodyer CG: Protein kinase C activation increases release of secreted amyloid precursor protein without decreasing Abeta production in human primary neuron cultures. J Neurosci 1998, 18:2907-2913.

48. Kim ML, Zhang B, Mills IP, Milla ME, Brunden KR, Lee VM: Effects of TNFalpha-converting enzyme inhibition on amyloid beta production and APP processing in vitro and in vivo. J Neurosci 2008, 28:12052-12061.

\section{doi:10.1186/1750-1326-6-69}

Cite this article as: Jiang et al: Elevated CSF levels of TACE activity and soluble TNF receptors in subjects with mild cognitive impairment and patients with Alzheimer's disease. Molecular Neurodegeneration 2011 6:69.

\section{Submit your next manuscript to BioMed Central and take full advantage of:}

- Convenient online submission

- Thorough peer review

- No space constraints or color figure charges

- Immediate publication on acceptance

- Inclusion in PubMed, CAS, Scopus and Google Scholar

- Research which is freely available for redistribution 